\title{
The Economic Value of Congo Basin Protected Areas Goods and Services
}

\author{
Jean Hugues NLOM, Ph.D \\ Faculty of Economics and Management, the University of Yaoundé II \\ POBOX: 1365 Yaoundé, Cameroon \\ E-mail: nlomhugues@yahoo.fr
}

\begin{abstract}
This paper describes the economic value of Protected Areas (PA) in the Congo Basin. It should be noted that the focus is on forest ecosystem values more generally, rather than PA values per se. This is because little or no specific information exists on the value of PAs in the sub-region, whereas data are available which look at the economic benefits associated with natural forests. In effect, the values referred to below therefore indicate the economic benefits that are generated from the conservation and sustainable use of forest biodiversity and ecosystems in the Congo Basin - to which ends which PAs provide an important conservation mechanism. The total economic value (TEV) is applied here as framework used to categorise ecosystem values. Data are coming from the existing literature in order to come up with broad estimates of the economic value of Congo Basin PAs. The main findings of this research estimate rely on different source data and calculation methods, represent a mixture of actual and potential values, and only consider key goods and services, it should be noted that the figures cannot be summed to give a single figure for the total economic value of Congo Basin PAs. As final results, the TEV is around US\$ 603,468,014,907 with US\$ 13,884,954 for direct use value; US\$ 589,532,157,606 for indirect use value and US\$ 50,903,301 for option, existence and bequest value. Henceforth, to maintain the sustainability of Congo basin, there is a need to provide adequate financing for protected areas. While precise figures are difficult to obtain, there is unquestionably a high economic and development value to protected area conservation. In many cases this value far exceeds those arising from alternative - and less sustainable — land and resource use options.
\end{abstract}

Keywords: Total economic value, Congo basin, Protected areas, Forest ecosystem

\section{A framework for looking at the economic value of Congo Basin Protected Areas}

Although conventional economic analysis tends to focus only on the physical products and marketed commodities that PAs yield (for example timber and tourism), the total economic value of ecosystems is in reality far greater than this. As the following sections will describe, Congo Basin PAs generate a wide range of goods and services that are used for income and subsistence, provide vital life support and underpin other economic activities and sectors, or hold significance regardless of their actual use. In many cases these economic values far exceed the monetary gains and profits from the direct exploitation of forest resources in formal markets - and to exclude them would massively underestimate the true social and economic value of PAs (Lescuyer, 1998).

For this reason, the paper looks at the total economic value of Congo Basin PAs and forests. Since it was first developed in the late 1980s and early 1990s (Barbier, 1989; Pearce \& Turner, 1990), "Total Economic Value" (commonly shortened to TEV) has become the standard and most widely applied framework used by economists to categorise ecosystem values. The major innovation of TEV is that it extends beyond the marketed and priced commodities to which economists have conventionally limited their analysis, and considers the full gamut of economically important goods and services associated with ecosystems. This is of key importance in a region such as the Congo Basin, where formal market transactions do not always dominate economic systems. Although it is no easy matter to quantify these values in countries like Cameroon, Central African Republic, Congo, Democratic Republic of Congo and Gabon, where money is not always the dominant form of exchange (Lescuyer, 1998) and where prices and markets do not exist for most ecosystem services, a range of methods have been developed which enable them to be expressed in monetary terms.

Looking at the TEV of Congo Basin forests involves considering their complete range of characteristics as integrated systems - resource stocks or assets, flows of environmental services, and the attributes of the ecosystem as a whole, including (Figure 1. the total economic value of Congo Basin forests):

- Direct values: the raw materials and physical products that are used directly for production, consumption and sale such as those providing income, energy, shelter, foods, medicines and recreational facilities.

- Indirect values: the ecological functions that maintain and protect natural and human systems through services such as maintenance of water quality and flow, flood control, micro-climate stabilisation and carbon sequestration.

- Option values: the premium placed on maintaining a pool of species and genetic resources for future possible uses, some of which may not be known now, such as leisure, commercial, industrial, agricultural and pharmaceutical applications and water-based developments.

- Existence values: the intrinsic value of ecosystems and their component parts, regardless of their current or future use possibilities, such as cultural, aesthetic, heritage and bequest significance. 
Over recent years it has become commonplace to conceptualise ecosystem services in terms of the framework laid out in the Millennium Ecosystem Assessment (MEA) ( Millenium Ecosystem Assessment, 2005), which relates the provisioning, regulating, supporting and cultural services of ecosystems to various aspects of human wellbeing. Each of the categories of TEV correspond to a different component of the MEA framework: direct values to provisioning services, indirect values to supporting and regulating services, existence values to cultural services, and option values potentially cross-cutting all four categories of MEA service. The two overlapping frameworks, within which the forest ecosystem values of the Congo Basin are categorised in this paper, are illustrated in Figure 1.

\section{Summary of the economic value of Congo Basin PA goods and services}

There is a paucity of reliable quantitative data on the economic value of ecosystem goods and services in Congo Basin countries. Although several detailed studies on the economic value of forest environmental goods and services have been carried out over the last decade in Cameroon(Note 1), there is only one comprehensive study of the economic value of forest ecosystems. This was carried out in 2007 by CIFOR, CIRAD and the World Bank, and focuses on the Democratic Republic of Congo (Debroux, Hart, Kaimowitz, Karsenty, \& Topa, 2007). The current paper takes the basic framework for analysis and the key assumptions from this study, and extends and updates them with data provided from literature in order to come up with broad estimates of the economic value of Congo Basin PAs. Indicative gross values(Note 2) are presented for key goods and services. As the estimates rely on different source data and calculation methods, represent a mixture of actual and potential values (i.e. not all of the values presented are currently being captured), and only consider key goods and services, it should be noted that the figures cannot be summed to give a single figure for the total economic value of Congo Basin PAs.

It is also important to underline that the figures presented below are indicative estimates only, aiming to provide broad-brush approximations of the scope and magnitude of PA values. As such, they should be treated with caution. They are based on many different secondary data sources, which are of varying credibility and reliability. The value estimates are of necessity partial, depend on a large number of assumptions about the relationships which exist between PA ecosystems and economic processes, and often involve the broader extrapolation of data which have been generated in specific sites or at a particular time.

Details of the many assumptions made in the calculations presented below, and the data sources they have been based on, are provided in the annex to this report.

Finally, it should be emphasised that the values presented in this paper inevitably cover only a tiny proportion of the total economic value of Congo Basin PAs. Only selected goods and services have been able to be quantified in monetary terms, since many natural assets are not easily to value in monetary terms in Congo Basin countries (Lescuyer, 1998). In most cases these both rely on very conservative assumptions, and thus probably underestimate the true scale of benefits. Indeed, many of the values associated with Congo Basin PAs - especially those relating to cultural, existence and option values - cannot be quantified, and in some cases represent immeasurably large values.

It is however worth underlining that, however imperfect currently available information is, this kind of wider quantification of ecosystem economic values makes an important point that both there is a high (although largely unrecognised) economic and development value to PA conservation, and in many cases this value far exceeds other less sustainable land and resource use options. For example the total economic value of a tropical forest in the East Cameroon region has been valued at US\$ 1,561/ha (Lescuyer, 2000). This includes timber (logging), NTFP and carbon sequestration. The total economic value of Ivindo National Park in Gabon has been estimated at US\$ 76.6 million(Note 3)(Lescuyer, 2006), including ecotourism, carbon sequestration, and non-use values. This compares to a logged value of US\$ 32.4 million. A value of US\$1,175/ha has been attributed to the conservation of tropical forest in Cameroon (Ngo Nonga, 2002), where only harvesting of NTFP and medicinal product are allowed, as well as factoring in the value of carbon sequestration.

The intention is to represent and underline the key importance of Congo Basin forest ecosystems to local, national and even global economic processes, beyond the (mainly timber) benefits that are reflected in conventional economic analyses and official statistics. According to WWF, approximately 30 million people, representing more than 150 indigenous groups, live in the Congo River Basin portion of the countries which are included in this project (out of a total population of more than 90 million people (UNDP, 2009)); in total, more than 77 million people live in the Congo Basin (De Wasseige, Devers, De Marcken, Eba'a Atyi, Nasi, \& Mayaux, 2008). Almost all of this human population depend in some way on PA goods and services. The figures presented below make the point that PAs constitute far more than a static stock of biological and ecological resources - they represent a valuable natural asset, which if managed wisely and sustainably will continue to yield these economic values in perpetuity.

\section{Direct values / provisioning services}

\subsection{Timber}

Immense values have long been generated from the exploitation of timber resources in Congo Basin countries although the formal forestry sector's contribution to GDP has been consistently decreasing over time, especially 
for countries where the oil and minerals sectors have been growing (De Wasseige, Devers, De Marcken, Eba'a Atyi, Nasi, \& Mayaux, 2008). Currently, it is estimated that the formal forestry sector contributes between $0.2 \%$ (in Equatorial Guinea) and $6.0 \%$ (in Cameroon) to GDP, and earns almost $€ 120$ million in tax income each year for the governments of Congo Basin countries (

Table). In addition, it generates a range of other benefits to the national economy: in Central African Republic (CAR) for example timber comprises $41 \%$ of all export earnings, and in both CAR and Gabon the forestry sector is the second largest employer after the state (De Wasseige, Devers, De Marcken, Eba'a Atyi, Nasi, \& Mayaux, 2008). Forest companies also often play a significant role in terms of construction and maintenance of roads, classes, development of water wells and village electrification.

The formal forestry sector in Congo Basin countries produces more than 10 million tonnes of timber a year (Table), with production dominated by Gabon (3.96 million tonnes) and Cameroon (3.16 million tonnes). A large proportion of this timber is exported - around 50\% overall, ranging from $15 \%$ in Central African Republic to over $90 \%$ in the Democratic Republic of Congo. The current total annual value of these exports exceeds US\$ 2.5 billion, while the estimated market value of domestically-consumed timber and timber products is estimated to total almost US\$ 1 billion.

Data for Cameroon, CAR, Congo, DRC and Gabon sourced from ITTO Annual Review of World Timber 2010; for Equatorial Guinea from FAOSTAT. Export prices and values as stated in these sources; value of domestically-consumed timber assumes $50 \%$ of f.o.b. export price as average. *as export volumes exceed production, it is concluded that a proportion of trade involves re-exports; as data are not available on domestically-consumed production, values have not been calculated.

It is likely that in Congo Basin countries, the informal forestry sector is at least as important as the formal sector although reliable data do not exist about the exact volume of timber extracted. One estimate for the Democratic Republic of Congo suggests that informal timber harvesting totals around 1.5 to 2.5 million $\mathrm{m}^{3}$ a year: between four and six times as much as officially-recorded production (Djiré, 2009 cited in Debroux et al, 2007). If we take a conservative estimate of informal harvesting at twice the recorded figure of formal sector timber production, and apply domestic market prices, this suggests a minimum annual value of some US\$ 4.3 billion.

\subsection{Woodfuel}

Woodfuel is the dominant energy source in both rural and urban areas of the Congo Basin, and most is sourced from natural forest areas (De Wasseige, Devers, De Marcken, Eba'a Atyi, Nasi, \& Mayaux, 2008). Annual consumption is recorded at around 95 million $\mathrm{m}^{3}$, mainly comprised of firewood, with a total value of some US $\$ 2.8$ billion (Table ).

\subsection{Non-wood forest products}

Non-wood forest products (NWFP) are arguably the most important direct use value obtained from Congo Basin forests, because they are so vital to the income, nutrition and health of a large proportion of the rural population. A study in the tropical forests of East Cameroon has, for example, found an economic value for NWFP harvesting of around US\$ 54/ha/year (Lescuyer, 2000).

Bushmeat provides a significant and direct source of protein. Overall, approximately $80 \%$ of the volume of meat eaten in Congo Basin countries comes from wild animals (Biodiversity Support Program, 2001), which contributes between $30 \%$ and $80 \%$ of the protein consumed by forest-dwelling families (Usongo \& Nagahuedi, 2008). In many places this rises as high as $98 \%$ (Tchamie, 1996). It provides a cheap and easily-accessible source of nutrition, and plays a vital part in the diets, livelihoods and food security of rural households (Bowen-Jones, Brow, $\&$ Elizabeth Robinson, 2002), especially during the hungry season and in situations of stress and emergency (De Merode, Homewood, \& Cowlishaw, 2003). Around the Dja Reserve for example bushmeat contributes up to $98 \%$ of protein intake of nearby communities and in Gabon up to 73\% (Bowen-Jones, Brow, \& Elizabeth Robinson, 2002). Among a Ntomba community in the Democratic Republic of Congo, bushmeat, fish and insects provide $47 \%$ of protein (Hoare, 2007). Around Camp Ma'an National Park in Cameroon, local people derive most of their income and food from hunting and fishing (Dounias, 1993). A hunter can earn up to US\$28 a month (Nlom, 2009). It is estimated that the rural revenue generated by bushmeat is at least equal to, and possibly more than, that produced by the formal logging industry (Usongo \& Nagahuedi, 2008).

A comprehensive study of the total volume of bushmeat harvesting, for both home consumption and sale, estimates total annual consumption to be in excess of 1 million tonnes a year, or an average of $35 \mathrm{~kg}$ per capita (Table ) (Imandar, Brown, \& Cobb, 1999). At local market prices, this translates into an annual value of nearly US\$ 3 billion. It is worth noting that this probably represents a conservative estimate, as other studies put this figure at a much higher level. In the Democratic Republic of Congo alone, bushmeat consumption has been estimated to be between 1.1 and 1.7 million tonnes a year (Debroux, Hart, Kaimowitz, Karsenty, \& Topa, 2007), and it has been proposed that the total annual harvest across the sub-region exceeds 2 million tonnes (Nasi \& Van Vliet, 2008). 
Other NWFP which are harvested from Congo Basin forests and PAs include a diverse range of products used for income, shelter, food, medicines and handicrafts. More than half of the population in Central Africa takes part in the harvest of NWFP (Ndikumagenge \& Ngome). One feature of NWFP is that they are often collected and traded by women, and so help to increase their income and livelihood status. For example, in the humid forest zone of Cameroon, an estimated 94\% of the traders of NWFPs are women (Ndoye \& Tieguhong, 2004). However, while women tend to dominate the collection and trade of many NWFP, men are more involved in the harvest of higher-value commodities such as rattans, bushmeat and medicinal plants (Hoare, 2007).

NWFP provide important sources of cash income for many households. In Equateur Province in the Democratic Republic of Congo, for example, households selling NWFP (including leaves, caterpillars, mushrooms, charcoal and palm wine) earn a monthly income of US\$ 84 , equivalent to or higher than that of a civil servant or a secondary school teacher (Ndoye, Awono, Preece, \& Toirambe, 2007). For local traders the monthly profit from selling the same range of products is between US\$ 130 and US\$216, roughly equivalent to that of a doctor, and for those trading in Kinshasa income can reach as high as US\$ 1,352. For the Azande in the Democratic Republic of Congo, wild foods comprise around one third of household production, as compared to a half from crops (De Merode, Homewood, \& Cowlishaw, 2003). They however contribute much more to household income (about twice as much as crops, or a quarter of all household sales).

NWFP sourced from Congo Basin countries also supply international export markets. Five products(Note 4) alone have an annual turnover of US\$ 45 million, supplying both domestic and export markets (Ingram, 2009). Annual imports of NWFP into France, UK, Belgium, Spain and Portugal include an estimated 32,000 tonnes coming from Congo Basin countries, worth more than US\$ 96 million (Hoare, 2007).

Medicinal plants are another key NWFP sourced from forests in the Congo Basin. Up to $80 \%$ of Cameroonians use wild medicinal plants to cater to all or part of their healthcare needs, and more than $90 \%$ in the Democratic Republic of Congo (Ingram, 2009). For example, around Mbalmayo Forest Reserve, more than $70 \%$ of the population depend on plant-based medicines, which are $50-90 \%$ cheaper than their bought alternatives (Hoare, 2007). In a survey in Equateur and Bandundu Provinces of the Democratic Republic of Congo, $85 \%$ of households were found to use medicinal plants to cure common ailments, and another study from South Kivu Province found that $95 \%$ of people use traditional medicines (Hoare, 2007). The annual income for medicinal plants has been estimated at between US\$ 0.7ha/year (Ruitenbeek, 1990) and US\$ 18/ha/year (Lescuyer, 2000) in Cameroon.

\subsection{Tourism}

Congo Basin PAs support both nature tourism and recreational hunting. Poor tourist infrastructure, combined with the region's perceived insecurity, history of civil unrest and high levels of corruption, as well as the relative inaccessibility of many PAs, however means that the region's tourism remains relatively undeveloped - with the notable exception of gorilla tourism, particularly in the north of the Democratic Republic of Congo.

Little or no information exists on the scale or value of hunting: there are no published accounts and few unpublished sources of information, and safari hunting companies are disinclined to discuss their operations and profitability (Wilkie \& Carpenter, 1999). Various figures for the economic value of PA tourism in Congo Basin countries do however exist (De Wasseige, Devers, De Marcken, Eba'a Atyi, Nasi, \& Mayaux, 2008). In Cameroon, it is estimated that biodiversity-related tourism contributed $1.35 \%$ to the balance of trade and provided tax earnings of about $€ 697,000$ in 2007 . The biodiversity-related tourism sector is thought to directly employ nearly 800 people in CAR and provided tourist revenues estimated at nearly $€ 1$ million. The recreational value of gorilla in Dja Wildlife Reserve in Cameroon has been estimated at US\$192/tourist (Nkolo Ndzodo, 2005).The economic value of ecotourism potential in Ivindo National Park in Gabon has been calculated to be US\$1.4 million for the sites of Kongou and Baï de Langoué Waterfalls, and between US\$125 - 170 per tourist day for gorillas (Lescuyer, 2006).

Gorilla tourism is one of the most well-developed, and lucrative, sources of international tourism in to the PAs of the Congo Basin. Recent estimates (Hatfield \& Malleret-King, 2007) have been made of the total value of this tourism for the four PAs of the Bwindi/Virunga forest region: Bwindi Impenetrable Forest and National Park in Uganda, Parc des Volcans in Uganda, Park de Virunga Sud in the Democratic Republic of Congo, and Mgahinga Gorilla Park in Uganda. Just looking at the Ugandan and Rwandan portions of this landscape, every international visitor spends an average of US\$1,254 on gorilla-viewing travel; in addition, each gains an average of US\$953 in consumer surplus(Note 5). It is further estimated that of this total, around 36\% is retained in-country.

The same study also estimates the current international gorilla tourism potential of Park de Virunga Sud in the Democratic Republic of Congo to be in the region of 20,000 visitors a year. Although this assumes the renovation and rebuilding of tourist infrastructure and a return of international confidence in the Democratic Republic of Congo as a tourist destination, it is based on actual pre-war tourism figures and on gorilla tourism to neighbouring countries and PAs, and may therefore be a realistic estimate. Based on these figures, and on the per capita values imputed to gorilla tourism in Rwanda and Uganda, this suggests a potential value of US\$ 44.14 million a year, of which US\$ 15.89 million might be retained in-country. 


\section{Indirect values / supporting and regulating services}

\subsection{Watershed protection}

According to the World Resources Institute, the Congo River Basin drains a watershed area of $3,730,474 \mathrm{~km}^{2}$. It covers all of the Democratic Republic of Congo, as well as parts of Congo, Cameroon, the Central African Republic, Equatorial Guinea, Burundi, Tanzania, Zambia and Angola. PAs and forests provide important protection services to the Congo watershed, as well as several other major basins - the Ogooué, Sanaga, Cross and the lower Niger, and a number of smaller basins which drain into the Gulf of Guinea (De Wasseige, Devers, De Marcken, Eba'a Atyi, Nasi, \& Mayaux, 2008). The Congo Basin is however by far the largest, with annual renewable water resources of about 1.3 billion cubic metres, supporting more than 77 million people (De Wasseige, Devers, De Marcken, Eba'a Atyi, Nasi, \& Mayaux, 2008).

Forested PAs yield a number of important water-related ecosystem services, including water supply, flow regulation, control of siltation and sedimentation, and water quality. Unfortunately, a severe lack of hydrological research and data mean that little is known of the exact relationships between forests and hydrological processes in Congo Basin countries. Forested PAs do however clearly play an important role in downstream water supplies and water quality: for domestic and industrial use, irrigation, hydropower and other activities. Watershed protection is particularly important to the hydropower industry, which currently represents most of the installed capacity for generating electricity in Congo Basin countries. In 2008, the total installed operational capacity for hydropower fed by Congo Basin Rivers was reported at 6,490 MW(Note 6), 3,634 MW or almost 56\% of which is located in the project countries (mainly the Democratic Republic of Congo).

Looking at the costs avoided of replacing natural forest watershed protection functions with artificial infrastructure, and assuming a per hectare value which is taken from forest areas in the broader region with similar conditions(Note 7) can be averaged across all forest in the Congo Basin, the annual value of these services may be in excess of US\$ 1.05 billion a year.

\subsection{Micro-climate and global rainfall}

A large part of the rainfall in the Congo Basin is thought to come from the recycling of moisture by the forest: it is estimated that between $75 \%$ and $95 \%$ of rainfall is recycled within the Congo Basin and that evaporation from the region contributes about $17 \%$ of rainfall in West and Central Africa (Mataé, 2008). Deforestation in the Congo Basin is thought to be having a strong effect on both local and global rainfall.

Regional-scale atmospheric simulation experiments have shown that deforestation in timber concessions could affect precipitation inside adjacent PAs in Congo and Gabon, indicating that in some parks rainfall reduced by as much as $15 \%$ as a result of loss of forest (Baidya Roy, Walsh, \& Lichstein, 2005). It is also asserted that deforestation in the Congo Basin causes a decrease in precipitation of 5-15\% in the Great Lakes region of the USA, and affects parts of Ukraine and Russia where May precipitation is reduced by as much as a quarter (Avissar \& Werth, 2005). Satellite observations on tropical rainfall distribution and historical river flow observations also appear to document a natural see-saw oscillation across the Atlantic Ocean, showing that floods over the Amazon basin tend to coincide with droughts over the Congo Basin and vice-versa (Eltahir, Loux, Yamana, \& Bomblies, 2004). Deforestation in the Congo Basin could thus have an important effect on this natural oscillation, as large variations in rainfall over the continental centres of convection and rainfall of the Amazon and the Congo are likely to have significant impacts on the hydrology and climate of surrounding regions (Mataé, 2008).

\subsection{Carbon sequestration}

Much attention has recently been focused on the role of Congo Basin forests in carbon sequestration, and the consequently devastating impacts of deforestation and forest degradation on global carbon emissions. Recent estimates made in the 2008 State of the Forests Report (De Wasseige, Devers, De Marcken, Eba'a Atyi, Nasi, \& Mayaux, 2008) estimate the total stock of carbon in Congo Basin forests to be some 47 billion tonnes (Table ).

Applying the average price for carbon in voluntary offset markets(Note 8), which represents a very conservative estimate of carbon values(Note 9), to the total carbon stored in the Congo Basin's humid and closed deciduous forests, deciduous woodlands and forest/savanna mosaics suggests that the total value of this carbon stock is some US\$ 585 billion.

This figure however refers to the total amount of carbon sequestered in the Congo Basin's forests. In order to come up with a meaningful annual figure, we can look at the carbon sequestration value of forests in terms of costs avoided - in other words what PAs and other forms of conservation land use may save in terms of avoided deforestation and forest degradation. According to a recent study based on FAO estimates of deforestation (Mataé, 2008), the Congo Basin loses 65.9 million tonnes of carbon per annum. Applying the voluntary market value of US\$ 12.50/tonne of carbon, this translates into an annual value of some US\$ 0.86 billion a year. Alternatively, we can look at the value of carbon biomass stored, year on year, as compared to the next most likely land use in forest areas. Assuming a gradual conversion over the next century of forest and woodland in Congo Basin countries to forest/cropland mosaic and open woodland shows an average annual value(Note 10) of stored forest carbon of US\$ 2.5 billion. 


\section{Option and existence values / cultural services}

The option and existence values associated with Congo Basin PAs are immense, although - as explained earlier largely unquantifiable in monetary terms. Located in one of the world's biodiversity hotspots, and containing a huge variety of rare and endangered species, the continued conservation of PAs in the Congo Basin implies a substantial, although largely unknown, option value in terms of possible future uses and applications of wild resources and ecosystems.

Culturally diverse peoples have inhabited the forests of the Congo Basin for thousands of years, and over millennia local social and economic processes have been intimately entwined with nature (Toham, D'Amico, Olson, Blom, $\&$ al., 2003). The social, cultural, spiritual and traditional value of the species and ecosystems contained within the sub-region's PAs is vast, both for local populations and at the national and sub-regional level. At the same time, the rich and unique biodiversity and ecosystems that are contained in national PA networks hold a huge value for the global community, regardless of actual use, simply because they are known to exist.

In the absence of specific data, the global existence value of Congo Basin PAs can be tentatively - although only very partially - estimated by the flow of international donor assistance for nature conservation which, at present, is approximately US\$25 million per year (Galindo, 2010).

\section{Conclusion}

The forests of the Congo Basin provide important economic benefits to communities across the region. The formal timber sector, the informal timber sector, woodfuel, bushmeat, non-wood forest products and gorilla tourism these are just some of the direct values of Congo basin forests, valued at a minimum of US\$13 billion per year, and probably much more. In addition, indirect values such as watershed protection and carbon sequestration total billions more annually. And yet the sustainability of these economic benefits is in question. For the benefits accruing from natural assets like the Congo Basin forests are like interest earned annually on money in a bank. If we withdraw only the interest, and maintain the principle, we can continue to benefit from that interest in perpetuity. Yet if we allow the principle to shrink, then our annual interest will shrink as well. And if we continue in this manner, withdrawing the same amount or even more each year, then the shrinkage in our asset will accelerate until the asset, and the benefits, disappear altogether. One way to make sure that this doesn't happen to this region's forest assets is to establish and provide adequate financing to, protected areas. While precise figures are difficult to obtain, there is unquestionably a high economic and development value to protected area conservation. In many cases this value far exceeds those arising from alternative - and less sustainable - land and resource use options. Congo Basin forest ecosystems are important to local, national and even global economic processes in ways that go well beyond the mainly timber benefits that are reflected in conventional economic analyses and official statistics.

\section{References}

Millenium Ecosystem Assessment. (2005). Ecosystems and Human Well-Being: Synthesis. Washington DC: Island Press.

Avissar, R., \& Werth, D. (2005). Global Hydroclimatological Teleconnections Resulting From Tropical Deforestation. Journal of Hydrometeorology, 6, 134-145.

Baidya Roy, S., Walsh, P., \& Lichstein, J. (2005). Can Logging in Equatorial Guinea Affect Adjacent Parks? Ecology and Society, 10 (1), 6.

Barbier, E. (1989). Economics, Natural-Resources Scarcity and Development. London: Earthscan Publications.

Biodiversity Support Program, \&. B. (2001). Bushmeat Crisis Causes, Conseuquences and Controls. Kinshasa: Issues Brief \# 23, Congo Basin Information Series. Central African Regional Program for the Environment (CARPE).

Bowen-Jones, E., Brow, n. D., \& Elizabeth Robinson, E. (2002). Assessment of the Solution-orientated Research Needed to Promote a More Sustainable Bushmeat Trade in Central and West Africa. London: Produced for Department of Environment, Food and Rural Agriculture.

De Merode, E., Homewood, K., \& Cowlishaw, G. (2003). Wild Resources and Livelihoods of Poor Households in Democratic Republic of Congo. London: ODI Wildlife Policy Briefing, Overseas Development Institute.

De Wasseige, C., Devers, D., De Marcken, P., Eba'a Atyi, R., Nasi, R., \& Mayaux, P. (2008). The Forest of the Congo Basin: State of the Forest 2008. Lexembourg: Publications Office of the European Union.

Debroux, L., Hart, T., Kaimowitz, D., Karsenty, A., \& Topa, G. (2007). Forest in Post-Conflict DRC: Analysis of a Priority Agenda. CIFOR, the World Bank and CIRAD.

Dounias, E. (1993). Dynamique et Gestion Différentielle du Système de Production à Dominante Agricole des MVAE du Sud Cameroun Forestier. Thèse de Doctorat en Biologie Végétale Tropicale, Université de Montpellier, $490 \mathrm{p}$.

Eltahir, E., Loux, B., Yamana, T., \& Bomblies, A. (2004). A See-Saw Oscillation between the Amazon and Congo Basins. Geophysical Research Letters (31). 
Galindo, J. (2010). National Sustainable PA Financing baseline Assessments. Yaoundé, Cameroon: Report prepared for WWF CARPO under GEF/UNDP PIMS 3447: Sustainable Financing of Protected Area Systems in the Congo Basin.

Hatfield, R., \& Malleret-King, D. (2007). The Economic Value of the Mountain Gorilla Protected Forest (The Virungas and Bwindi Impenetrable National Park). Nairobi: International Gorilla Conservation Programme (IGCP).

Hoare, L. (2007). The Use of Non-Timber Forest Products in the Congo Basin: Constraints and Opportunities. London: The Rainforest Foundation.

Imandar, A., Brown, D., \& Cobb, S. (1999). What's Special about Wildlife Management in Forests? Concepts and Models of Rights-Based Management, with recent evidence from West-Central Africa. Natural Resource Perspectives (44).

Ingram, V. (2009). The Hidden Costs and Values of NTFP Exploitation in the Congo Basin. Buenos Aires: paper Presented at XIII World Forestry Congress.

Lescuyer, G. (2006). Evaluation Economique du Parc National de l'Ivindo au Gabon: Une Estimation des Bénéfices Attendus de la Conservation de la Nature en Afrique. Montpellier: Rapport Final, CIRAD-Forêt, UPR 36.

Lescuyer, G. (2000). Evaluation Economique et Gerestion Viable de la Forêt Tropicale: Reflexion sur un Mode de Coordination des usages d'une Forêt de l'EST-Cameroun. Paris: Thèse de Doctorat, Ecole des Hautes Etudes en Sciences Sociales (EHESS).

Lescuyer, G. (1998). Globalization of Environmental Monetary Valuation and Sustainable Development. An Experience in the Tropical Forest of Cameroon. International Journal of Sustainable Development, 1 (1), 115-133.

Mataé, D. (2008). Ecosystem services of the Congo Basin Forests. London: Foresight Report No. 3. Global Canopy Programme.

Nasi, R., \& Van Vliet, N. (2008). Hunting for Livelihood in Northeast Gabon: Patterns, Evolution and Sustainability. Ecology and Society, 13 (2), 33.

Ndikumagenge, C., \& Ngome, P. Quantifying NTFPs. ITTO Tropical Forest Update , 18/4.

Ndoye, O., \& Tieguhong, J. (2004). Forest resources and Rural Livelihoods: The Conflict between Timber and Non-timber Forest products in the Congo Basin. Scand. Journal for Res. , 19 (Suppl. 4), 1-9.

Ndoye, O., Awono, A., Preece, A., \& Toirambe, B. (2007). Markets in Non-Timber Forest Products in the Provinces of Equateur and Bandundu. Presentation on a Field Survey in BYC. What odes the future hold for the forest in DRC? Innovative Tools and Mechanisms for Sustainable Forest Management (Vol. 01). Kinshasa: Reflection and discussion Paper. Belgian development Agency.

Ngo Nonga, F. (2002). Gestion Soutenable de la Forêt Tropicale et Développement Intégré au Cameroun. Thèse de Doctorat d'Etat en sciences Economiques, Université de Yaoundé II-SOA.

Nkolo Ndzodo, L. (2005). Approche Economique des Bénéfices d'une Espèce Menacée d'Extinction: Le Cas du Gorille de la Plaine Occidentale de la Réserve de Faune du Dja au Cameroun. Libreville, Gabon: Mémoire de DEA en sciences économiques, Programme de Troisième Cycle interUniversitaire en Economie.

Nlom, J. (2009). Marché des Droits de Propriété et gestion Durable des Ressources Fauniques: Une analyse Exploratoire à la Périphérie du Parc National de Campo-ma'an au Cameroun. Thèse de Ph.D, Université de Yaoundé II-SOA.

Pearce, D. \&. (1990). Economics of Natural Resources and the Environment. Hemel Hempstead: Harvester Wheatsheaf.

Ruitenbeek, H. (1990). The Korup Project: Plan for Developing the Korup National Park and its Support Zone. London: WWF.

Tchamie, T. (1996). Aires Protégées au Togo: Nécessité d'une Redéfinition des Stratégies de Conservation et de protection de la Faune. Le Flamboyant (39), 12-15.

Toham, A., D'Amico, J., Olson, D., Blom, A., \& al., e. (2003). A Vision for Biodiversity Conservation in Central Africa: Biological Priorities for Conservation in the Guinean-Congolian Forest and Freshwater Region. Washington DC: WWF.

UNDP. (2009). Human Development Report 2009. Overcoming barriers: Human Mobility and Development. New York: United Nations Development Programme.

Usongo, L., \& Nagahuedi, J. (2008). Participatory Land-use Planning for Priority Landscapes of the Congo Basin. Unasylva , 230 (59). 
Wilkie, D., \& Carpenter, J. (1999). The Potential Role of Safari Hunting as a Source of Revenue for Protected Areas in the Congo Basin. Oryx , 33 (4), 339-345.

Note 1. Lescuyer G. 2000. Evaluation économique et gestion viable de la forêt tropicale : réflexion sur un mode de coordination des usages d'une forêt de l'Est CAMEROUN. Thèse de Doctorat, Ecole des Hautes Etudes en sciences Sociales (EHESS), Paris; Ngo Nonga F. 2002. Gestion soutenable de la forêt tropicale et développement intégrée au Cameroun. Thèse de Doctorat d'Etat en sciences économiques, Université de Yaoundé II-Soa. Lescuyer G. 2006. Evaluation économique du parc national de l'Ivindo au Gabon : Une estimation des bénéfices attendus de la conservation de la nature en Afrique. Rapport final, CIRAD Forêt, UPR 36. Montpellier.

Note 2. In other words, figures do not deduct harvesting, input, production, processing, transport and other intermediate consumption costs.

Note 3. About US\$ 255/Ha

Note 4. Honey, Gnetum spp., Irvingia spp., Dacyodes edulis and Prunus Africana

Note 5. The difference between what a consumer would be willing to pay for a good or service and what that consumer actually has to pay.

Note 6. This includes Angola, Burundi, Cameroon, CAR, Congo, DRC, Gabon, Rwanda, Tanzania and Zambia.

Note 7. The range of US\$ 3-10 per hectare per year is taken from Debroux et al 2007 op. cit., and averaged at US\$6.5/hectare/year. The total area of dense forest in the Congo Basin countries is cited as 161,987,859 hectares in de Wasseige et al 2008 op. cit.

Note 8. Currently between US\$ 5-20 per tonne of $\mathrm{CO}_{2} \mathrm{e}$; this report takes an average figure of US\$ 12.50 .

Note 9. As compared to, for example, the Shadow Price of Carbon calculations given in the Stern Review, the so-called "social costs" of carbon, avoided climate damage costs or emissions reductions costs.

Note 10. Using the common economic assumption that the further in the future a value accrues the less it is worth in today's terms, future forest carbon values are discounted (at a rate of $10 \%$ ) to bring them to present values.

Table 1. formal forestry sector contribution to GDP and tax earnings in Congo Basin countries (2007)

\begin{tabular}{|l|l|l|l|l|l|l|} 
& Cameroon & CAR & Congo & DRC & $\begin{array}{l}\text { Equatorial } \\
\text { Guinea }\end{array}$ & Gabon \\
\hline GDP (\%) & 6.0 & 6.3 & 5.6 & 1.0 & 0.2 & 4.3 \\
\hline $\begin{array}{l}\text { Tax earnings } \\
(€ \text { million) }\end{array}$ & 62.1 & -- & 10.0 & 1.7 & 13.8 & 31.3 \\
\hline
\end{tabular}

Source: Wasseige \& al, (2008) 
Table 2. value of formal sector timber production in Congo Basin countries (2007)

\begin{tabular}{|c|c|c|c|c|c|c|c|}
\hline & Cameroon & CAR & Congo & DRC & $\begin{array}{l}\text { Equatorial } \\
\text { Guinea }\end{array}$ & Gabon & Total \\
\hline \multicolumn{8}{|l|}{ Production } \\
\hline $\operatorname{Logs}\left(\mathrm{m}^{3}{ }^{\prime} 000\right)$ & 2,274 & 533 & 1,316 & 300 & 419 & 3,400 & 8,242 \\
\hline $\begin{array}{l}\text { Sawn timber }\left(\mathrm{m}^{3}\right. \\
\cdot 000)\end{array}$ & 773 & 95 & 268 & 92 & 4 & 296 & 1,528 \\
\hline Veneer $\left(\mathrm{m}^{3} \cdot 000\right)$ & 85 & 1 & 5 & 3 & 15 & 182 & 291 \\
\hline Plywood (m³ 000$)$ & 32 & 1 & 6 & 1 & -- & 85 & 125 \\
\hline All timber $\left(\mathrm{m}^{3} \cdot 000\right)$ & 3,164 & 630 & 1,595 & 396 & 423 & 3,963 & 10,171 \\
\hline \multicolumn{8}{|l|}{ Export } \\
\hline $\operatorname{Logs}\left(m^{3} \cdot 000\right)$ & 266 & 78 & 636 & 298 & 685 & 1,938 & 3,901 \\
\hline $\begin{array}{l}\text { Sawn timber }\left(\mathrm{m}^{3}\right. \\
\left.{ }^{\circ} 000\right)\end{array}$ & 613 & 18 & 136 & 63 & 6 & 253 & 1,089 \\
\hline Veneer $\left(\mathrm{m}^{3}{ }^{\prime} 000\right)$ & 64 & -- & 4 & 1 & 25 & 81 & 175 \\
\hline Plywood (m³ 000$)$ & 24 & -- & 2 & -- & -- & 58 & 84 \\
\hline All timber $\left(\mathrm{m}^{3}{ }^{\prime} 000\right)$ & 967 & 96 & 778 & 362 & $716^{*}$ & 2,330 & 4,533 \\
\hline \multicolumn{8}{|l|}{ Export values } \\
\hline Logs (US\$ ‘000) & 55,860 & 44,960 & 210,115 & 108,997 & 500,000 & 700,304 & $1,620,236$ \\
\hline $\begin{array}{ll}\text { Sawn } & \text { timber } \\
\text { (US\$ '000) } & \end{array}$ & 357,379 & 15,917 & 48,955 & 65,904 & 1,815 & 124,000 & 613,970 \\
\hline Veneer (US\$ ‘000) & 130,774 & 95 & 8,067 & 3,144 & 15,256 & 140,213 & 297,549 \\
\hline Plywood (US\$ ‘000) & 12,920 & -- & 966 & 159 & -- & 52,598 & 66,643 \\
\hline $\begin{array}{ll}\text { All } & \text { timber } \\
\text { (US\$ '000) }\end{array}$ & 556,934 & 60,971 & 268,102 & 178,203 & 517,071 & $1,017,114$ & $2,598,395$ \\
\hline \multicolumn{8}{|l|}{ Export prices } \\
\hline $\operatorname{Logs}\left(\mathrm{US} \$ / \mathrm{m}^{3}\right)$ & 210 & 575 & 326 & 366 & 730 & 361 & \\
\hline $\begin{array}{l}\text { Sawn } \\
\left(\mathrm{US} \$ / \mathrm{m}^{3}\right)\end{array}$ & 583 & 850 & 360 & 1,046 & 304 & 490 & \\
\hline Veneer $\left(\mathrm{US} \$ / \mathrm{m}^{3}\right)$ & 2,043 & 4,087 & 1,919 & 2,098 & 610 & 1,723 & \\
\hline Plywood (US\$/m³) & 538 & -- & 536 & 1,660 & -- & 907 & \\
\hline \multicolumn{8}{|c|}{ Value of domestically consumed timber* } \\
\hline Logs (US\$ ‘000) & 210,840 & 130,813 & 110,840 & 366 & n.d. & 263,891 & 716,750 \\
\hline $\begin{array}{ll}\text { Sawn } & \text { timber } \\
\text { (US\$ ‘000) } & \end{array}$ & 46,640 & 32,725 & 23,760 & 15,167 & n.d. & 10,535 & 128,827 \\
\hline Veneer (US\$ ‘000) & 21,452 & 2,044 & 960 & 2,098 & n.d. & 87,012 & 113,564 \\
\hline Plywood (US\$ ‘000) & 2,152 & - & 1,072 & 830 & n.d. & 12,245 & 16,299 \\
\hline $\begin{array}{ll}\text { All } & \text { timber } \\
\text { (US\$ } 000)\end{array}$ & 281,084 & 165,581 & 136,632 & 18,461 & n.d. & 373,682 & 975,439 \\
\hline
\end{tabular}

Source: Wasseige \& al, (2008) 
Table 3. value of woodfuel production in Congo Basin countries (2008)

\begin{tabular}{|l|l|l|l|l|l|l|l|}
\hline & Cameroon & CAR & Congo & DRC & $\begin{array}{l}\text { Equatorial } \\
\text { Guinea }\end{array}$ & Gabon & Total \\
\hline $\begin{array}{l}\text { Firewood } \\
\text { (cubic metres } \\
\text { '000) }\end{array}$ & $9,732.50$ & $6,016.50$ & $1,295.10$ & $74,315.30$ & 188.8 & 534.1 & $92,082.3$ \\
\hline $\begin{array}{l}\text { Charcoal } \\
\text { (tonnes ‘00) }\end{array}$ & 409.5 & 185.5 & 3.6 & $1,890.00$ & 8.5 & 19.2 & $2,516.3$ \\
\hline $\begin{array}{l}\text { Woodfuel value } \\
\text { (US\$000) }\end{array}$ & 304,260 & 186,060 & 38,961 & $2,286,159$ & 5,919 & 16,599 & $2,837,958$ \\
\hline
\end{tabular}

Data on production sourced from FAOSTAT 2010; values calculated using average price for Democratic Republic of Congo cited in Debroux et al 2007.

Table 4. value and volume of bushmeat consumption in Congo Basin countries

\begin{tabular}{|l|l|l|l|l|l|l|l|}
\hline & Cameroon & CAR & Congo & DRC & $\begin{array}{l}\text { Equatorial } \\
\text { Guinea }\end{array}$ & Gabon & Total \\
\hline $\begin{array}{l}\text { Total } \\
\text { consumption } \\
\text { (tonnes/yr) }\end{array}$ & 78,077 & 12,977 & 16,325 & $1,067,873$ & 9,763 & 11,381 & $1,196,396$ \\
\hline $\begin{array}{l}\text { Average harvest } \\
\text { (kg/km² forest/yr) }\end{array}$ & 503 & 248 & 77 & 897 & 574 & 50 & 645 \\
\hline $\begin{array}{l}\text { Average } \\
\text { consumption } \\
\text { (kg/person/yr) }\end{array}$ & 21 & 17 & 11 & 41 & 24 & 15 & 35 \\
\hline $\begin{array}{l}\text { Bushmeat value } \\
\text { (US\$ ‘00/yr) }\end{array}$ & 195,193 & 32,443 & 40,813 & $2,669,683$ & 24,408 & 28,453 & $2,990,990$ \\
\hline
\end{tabular}

Harvesting data sourced from Inamdar, A., Brown, D. and S. Cobb. (1999). Values calculated using average price for Democratic Republic of Congo cited in Debroux et al 2007.

Table 5. stock of carbon in Congo Basin forests (million tonnes)

\begin{tabular}{|c|c|c|c|c|c|c|c|}
\hline & $\begin{array}{l}\text { Cameroo } \\
\mathrm{n}\end{array}$ & CAR & Congo & DRC & $\begin{array}{l}\text { Equatorial } \\
\text { Guinea }\end{array}$ & Gabon & Total \\
\hline Humid forests & 3,203 & 886 & 3,263 & 18,056 & 383 & 4,033 & 29,824 \\
\hline $\begin{array}{l}\text { Mosaic } \\
\text { forest/croplands }\end{array}$ & 414 & 167 & 534 & 1,945 & 57 & 287 & 3,404 \\
\hline Mosaic forest/savanna & 628 & 2,437 & 145 & 3,059 & 3 & 20 & 6,292 \\
\hline $\begin{array}{l}\text { Closed deciduous } \\
\text { forest }\end{array}$ & 6 & 54 & 73 & 1,625 & 0 & 10 & 1,768 \\
\hline Deciduous woodland & 684 & 1,658 & 6 & 1,812 & 1 & 2 & 4,163 \\
\hline $\begin{array}{ll}\text { Open } & \text { deciduous } \\
\text { woodland }\end{array}$ & 108 & 258 & 199 & 760 & 0 & 31 & 1,356 \\
\hline Total & 5,043 & 5,460 & 4,219 & 27,258 & 445 & 4,383 & 46,808 \\
\hline
\end{tabular}

Data sourced from de Wasseige C., Devers D., de Marcken P., Eba'a Atyi R., Nasi R. and P. Mayaux (eds). The Forests of the Congo Basin - State of the Forest 2008. 


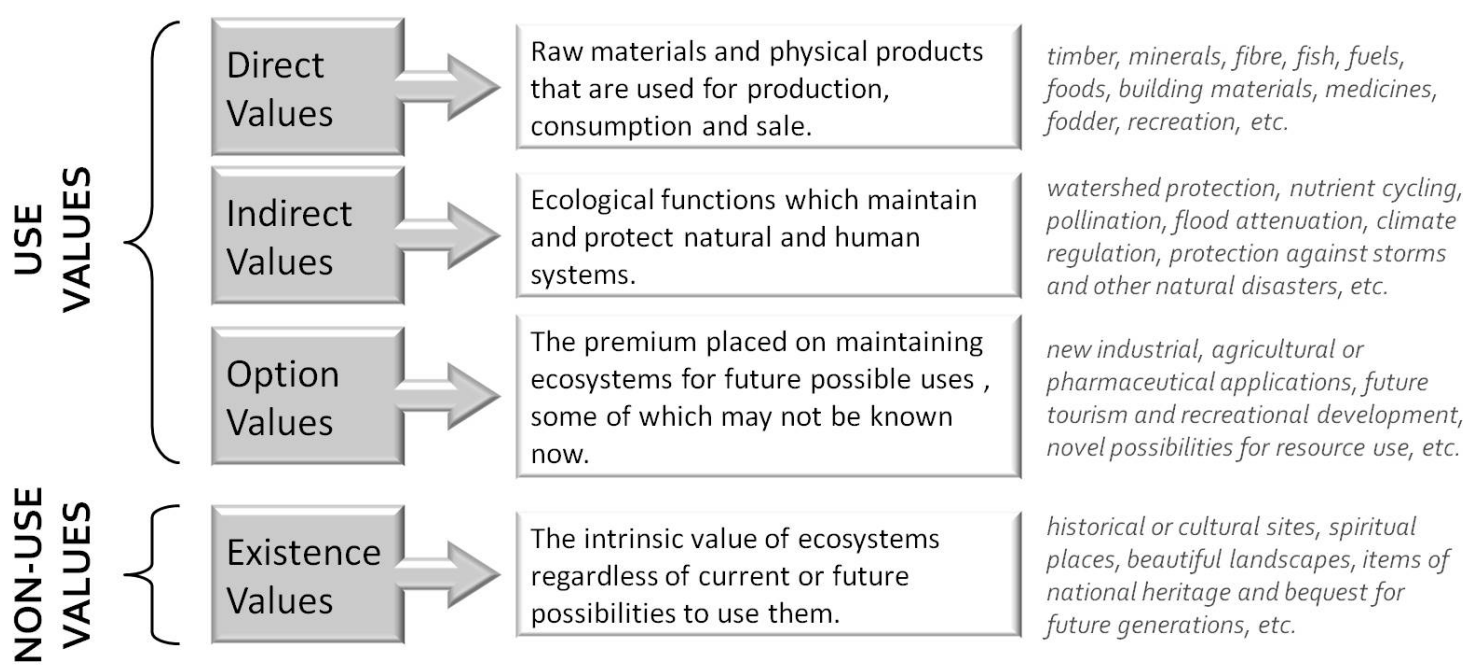

Figure 1. the total economic value of Congo Basin forests

Source: Pearce et al, (1990)

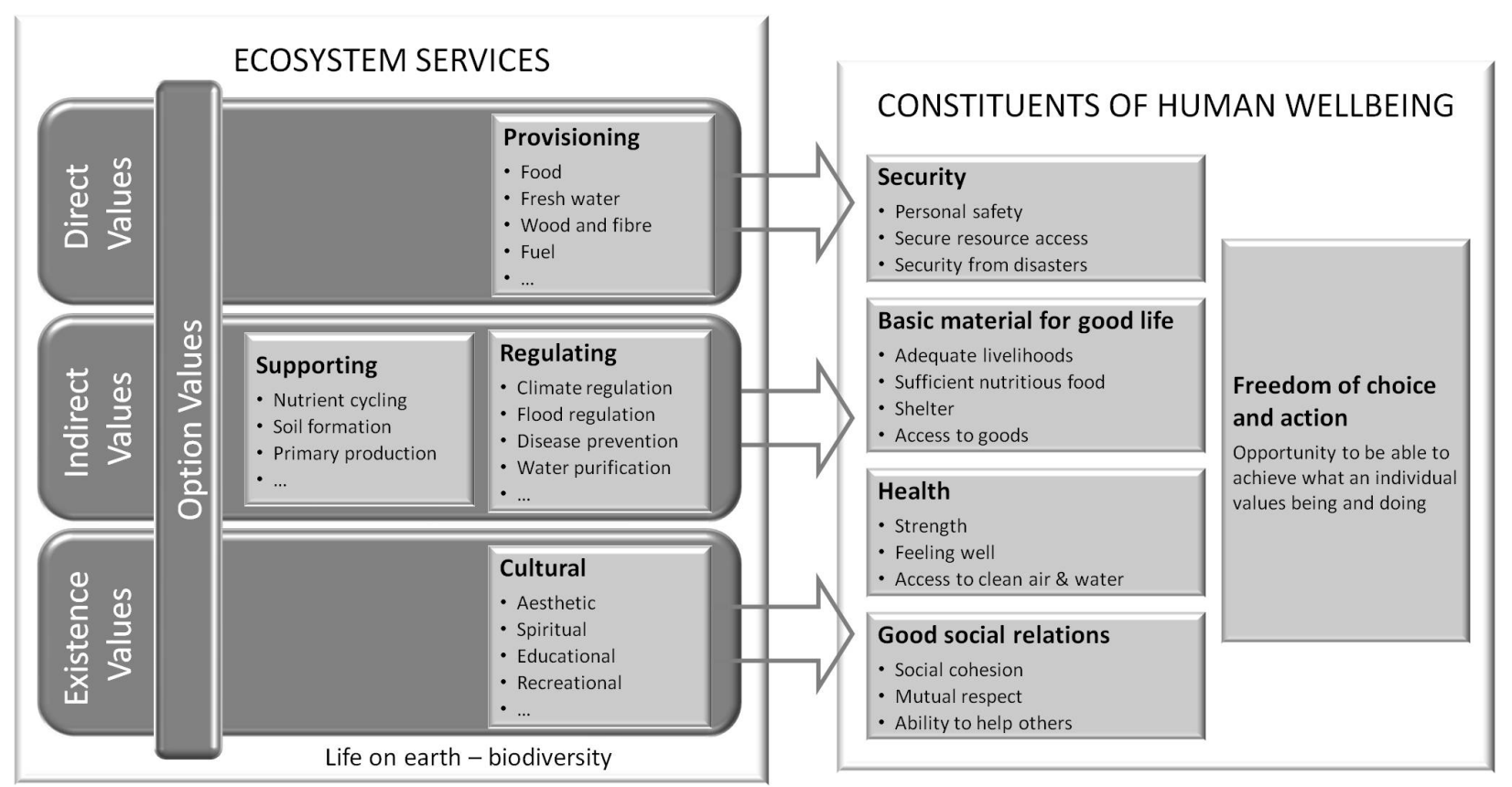

Figure 2. forest ecosystem services and economic values

Source: Millennium Ecosystem Assessment (2005) 


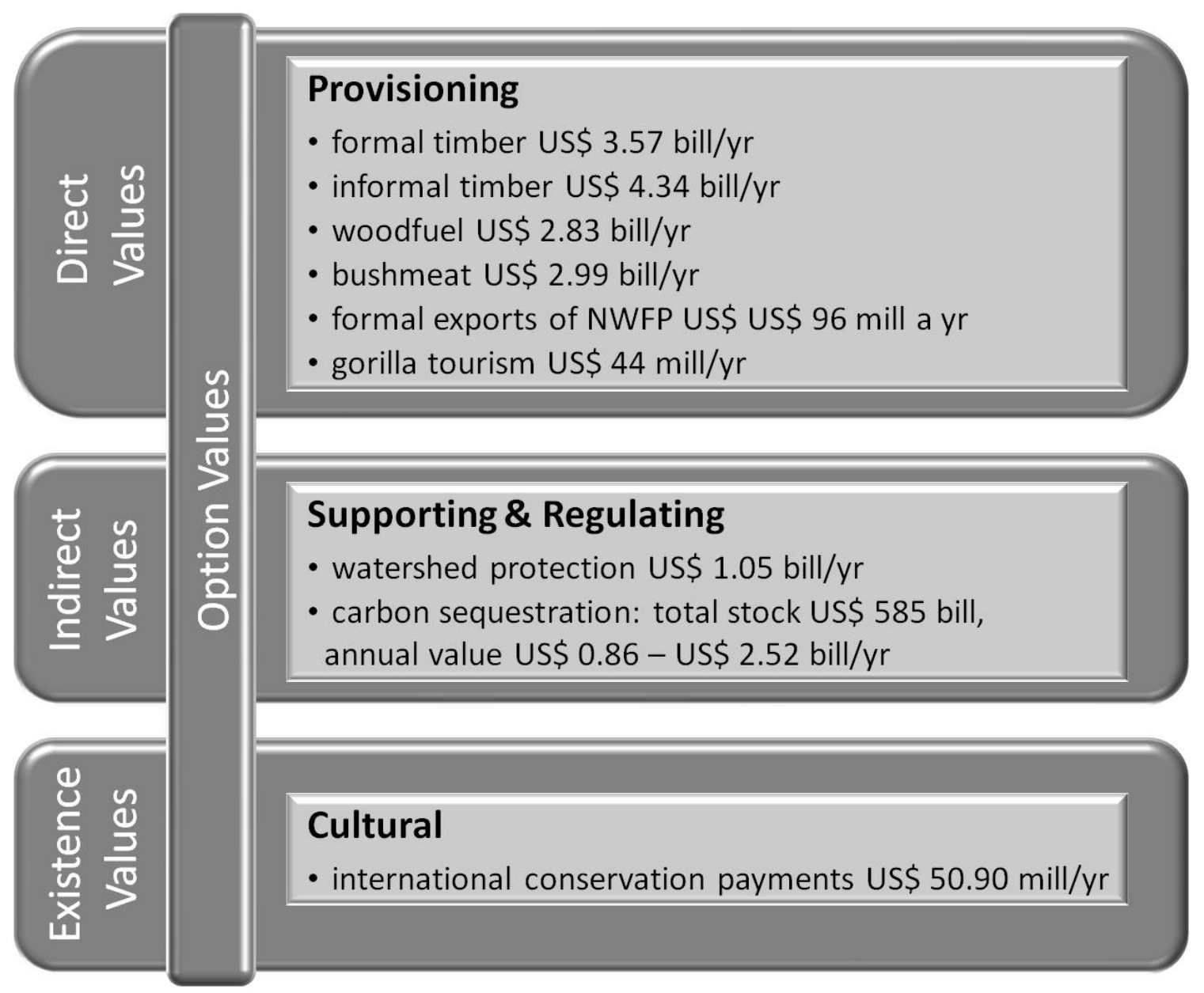

Figure 3. summary of key Congo Basin forest ecosystem values 
Annex: assumptions used to value forest ecosystem goods and services

\begin{tabular}{|c|c|c|}
\hline Good / service & Assumptions used in calculations & Estimated value \\
\hline $\begin{array}{l}\text { Formal timber } \\
\text { production }\end{array}$ & $\begin{array}{l}\text { Production volumes taken from ITTO } 2010 \text { and FAOSTAT. Export value uses } \\
\text { f.o.b. export price, domestically-consumed production valued at half of } \\
\text { this market price. }\end{array}$ & $\begin{array}{l}\text { Export value: US\$2,598,395,000 } \\
\text { Domestic value: US\$975,439,000 }\end{array}$ \\
\hline $\begin{array}{l}\text { Informal timber } \\
\text { production }\end{array}$ & $\begin{array}{l}\text { Informal production assumed to be double that of formal sector production, } \\
\text { all valued at local market prices }\end{array}$ & US\$ 4,342,032,000 \\
\hline Woodfuel & $\begin{array}{l}\text { Production volumes taken from FAOSTAT, values calculated using average } \\
\text { price for Democratic Republic of Congo cited in Debroux et al } 2007 \\
\text { (US\$30 / } \mathrm{m}^{3} \text { of firewood / charcoal) }\end{array}$ & US\$ 2,837,958,000 \\
\hline Bushmeat & $\begin{array}{l}\text { Production volume taken from Inamdar et al 1999, values calculated using } \\
\text { average price for Democratic Republic of Congo cited in Debroux et al } \\
2007 \text { (US\$2.5/kg) }\end{array}$ & US\$ 2,990,990,000 \\
\hline $\begin{array}{c}\text { Formal NWFP } \\
\text { exports }\end{array}$ & $\begin{array}{l}\text { Minimum value taken from Hoare 2007, referring to Congo Basin NWFP } \\
\text { exports to France, UK, Belgium, Spain and Portugal }\end{array}$ & US\$96,000,000 \\
\hline Tourism & $\begin{array}{l}\text { Potential gorilla tourism figures ( } 20,000 \text { visitors a year) and per capita values } \\
\text { (US\$1,254 travel costs and US\$953 consumer surplus) taken from } \\
\text { Hatfield and Malleret-King } 2007\end{array}$ & US\$ $44,140,000$ \\
\hline $\begin{array}{l}\text { Watershed } \\
\text { protection }\end{array}$ & $\begin{array}{l}\text { Dense forest area taken from de Wasseige C. et al 2008, forest watershed } \\
\text { value taken from Debroux et al } 2007 \text { (range of US\$ 3-10 per hectare per } \\
\text { year, averaged at US\$6.5/hectare/year) }\end{array}$ & US\$ 1,052,921,083 \\
\hline Carbon stock & $\begin{array}{l}\text { Forest carbon stock taken from Wasseige et al } 2008 \text { ( } 46,808 \text { million tonnes), } \\
\text { valued at voluntary offset markets carbon price (US\$ 5-20 per tonne, } \\
\text { averaged at US\$12.50/tonne) }\end{array}$ & US\$ $585,100,000,000$ \\
\hline \multirow[b]{2}{*}{$\begin{array}{l}\text { Annualised carbon } \\
\quad \text { value }\end{array}$} & $\begin{array}{l}\text { Costs of deforestation avoided using emissions figure taken from FAO in } \\
\text { Matae } 2008 \text { ( } 65.9 \text { million tonnes a year), valued at voluntary offset } \\
\text { markets carbon price (US\$ } 5-20 \text { per tonne, averaged at } \\
\text { US\$ } 12.50 / \text { tonne) }\end{array}$ & US\$ $861,250,000$ \\
\hline & $\begin{array}{l}\text { Additional value of carbon retained by forest over and above that stored by } \\
\text { alternative land uses of open woodland and mixed farm/forest. } \\
\text { Progressive conversion of existing forest to open woodland and mixed } \\
\text { farm/forest over the next century (using forest area figures taken from } \\
\text { Wasseige et al } 2008 \text { and assuming steady conversion rate of all forest), } \\
\text { using per hectare sequestration rates provided in Wasseige et al } 2008 \text {, } \\
\text { valued at voluntary offset markets carbon price (US\$ 5-20 per tonne, } \\
\text { averaged at US\$ } 12.50 / \text { tonne) with future values discounted at } 10 \% \text { rate } \\
\text { and resulting total annualised as average per year figures over the } 100 \\
\text { year period. }\end{array}$ & US\$ 2,517,986,523 \\
\hline $\begin{array}{l}\text { Option, existence } \\
\text { and bequest }\end{array}$ & Donor assistance to protected areas taken from Galindo 2010 & US\$ 50,903,301 \\
\hline
\end{tabular}

